\title{
ASSESSMENT OF SLOPE STABILITY AND REMEDIAL MEASURES AROUND GILGEL GIBE-II HYDROELECTRIC PROJECT, SOUTHWEST ETHIOPIA
}

\author{
Engdawork Mulatu ${ }^{1}$, Tarun Kumar Raghuvanshi ${ }^{2, *}$ and Bekele Abebe ${ }^{2}$ \\ ${ }^{1}$ Gilgel-Gibe II Hydroelectric Project, Fofa Town, Ethiopia \\ ${ }^{2}$ Department of Earth Sciences, College of Natural Science, Addis Ababa University, \\ PO Box 1176, Addis Ababa, Ethiopia. Email: tarunraghuvanshi@yahoo.com or \\ tkraghuvanshi@gmail.com
}

\begin{abstract}
A road constructed from Fofa town to Gilgel Gibe-II powerhouse in south-western Ethiopia passes through an extremely rugged terrain characterized by steep hill slopes and deep valleys. The present study has been carried out to identify potentially unstable slope sections and to work out proper remedial measures. In order to identify potential unstable slopes in the study area field investigations for slope stability analysis were undertaken. Further, based on the field manifestations of instabilities eight potentially unstable slopes were identified. Out of these, seven slope sections show potential for planar mode of failure whereas, one slope shows a potential for wedge mode of failure. The detailed stability study of these critical slope sections has been carried out by limit equilibrium method. The slopes having planar mode of failure were analyzed by using Sharma et al. (1995) technique, whereas the slope having wedge mode of failure was analyzed by 'SASW' computer program. The stability analysis was carried out for the existing and anticipated worst conditions. The results indicate that all critical slopes in the study area are stable for the existing conditions, represented by dry static conditions whereas for the anticipated worst conditions (i.e., moderately saturated slope with dynamic ground condition) slopes may become unstable. Based on the results of the stability condition, suitable remedial measures, such as safe cut slope design, rock bolt anchoring and suitable drainage requirements have been worked out for the critical slope sections.
\end{abstract}

Key words/phrases: Factor of safety, plane failure, slope design, slope stability, wedge failure

\section{INTRODUCTION}

The present study area lies in the Southern Nations, Nationalities and Peoples (SNNP) Regional State in the western margin of the central Main Ethiopian Rift and is bounded by Oromia Regional State and by Gibe River in the western and eastern sides, respectively. Geographically, the area is bounded by latitude 857000 to $869000 \mathrm{~N}$ and longitude 335500 to 343000 E UTM and falls within the Omo-Gibe River Basin (Fig. 1), which is one of the largest basins in south-western Ethiopia. The Gilgel Gibe II Hydroelectric Project area can be accessed from Addis Ababa by road to Fofa town, which is about $280 \mathrm{~km}$ on Addis Ababa-Jimma road.

The climate of the area is semi-arid. The daily average temperature varies between $12^{\circ} \mathrm{C}$ to $28^{\circ} \mathrm{C}$. There is only one distinct rainy season (from June to August) for which the long term annual average precipitation is $1320 \mathrm{~mm}$. The highest monthly average precipitation recorded was $314 \mathrm{~mm}$ in July 1996. An average minimum monthly rainfall of $15.7 \mathrm{~mm}$ has been recorded in the month of December from 1989 to 2005.

Physiographically, the study area falls in the Yem Zone, which is found partly in the western margin of the Main Ethiopian rift. The area is extremely rugged and the variation in the elevation is very large. The maximum elevation in the project area is about $2640 \mathrm{~m}$ near Fofa town and the minimum is $920 \mathrm{~m}$, which is the bed elevation of the Gibe River. Most of the streams flow along escarpments. The study area is bounded in the eastern side by a major escarpment along Gibe River, which has similar orientation with main Ethiopian rift system in the eastern side of the river. Most of the escapements are aligned parallel to two major tributaries namely, Derbu and Kora. At higher elevation, relative relief,

\footnotetext{
* Author to whom all correspondence should be addressed.
} 
which is the difference between the minimum and maximum elevation within a slope (Anbalagan, 1992; Varnes, 1984), is moderate (101m to $300 \mathrm{~m}$ ). Out of the total study area, around $75 \%$ falls under high relative relief, which is more than 300m (Fig. 2) (Engdawork Mulatu, 2005; Engdawork Mulatu et al., 2009). The drainage pattern of the study area is dendritic type and most of the tributary streams are aligned parallel to structural weaknesses, mainly faults. The major tributaries of Gibe River in the study area are Derbu and Kora streams, which are seasonal.

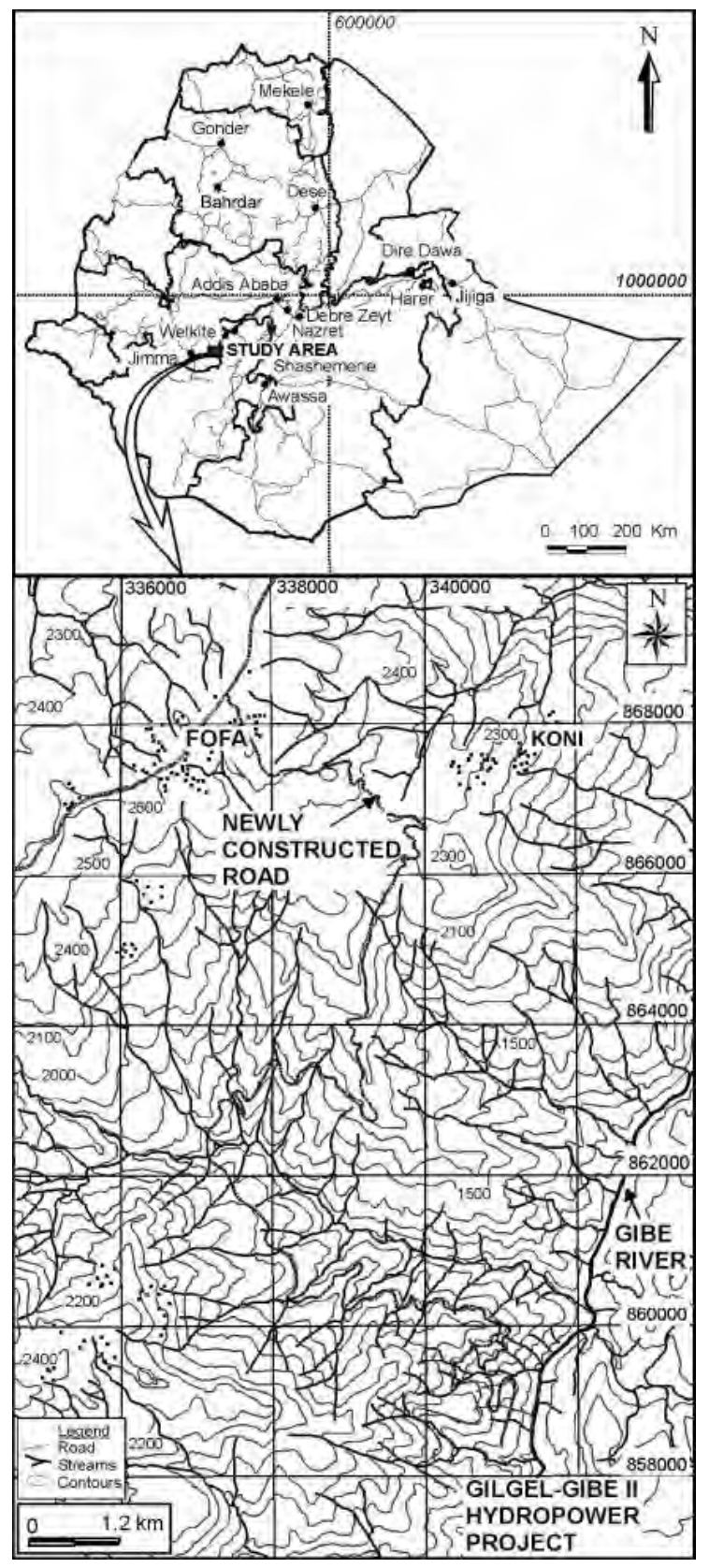

Fig. 1. Location map of the study area.

\section{GEOLOGY}

The Omo river canyon exposes more than $1 \mathrm{~km}$ thick sediments and volcanic rocks. The general volcanic stratigraphy in the Omo region, west of Soddo town comprises from bottom to top Middle Miocene rhyolites and trachytes, $15 \mathrm{Ma}$ trachytes, $10 \mathrm{Ma}$ basalts and mugearites covered with Pliocene basalts, ignimbrites and trachytes (Giday WoldeGabriel et al., 1990; Tierrcelin et al., 1980; Kazmin and SeifeMichael Berhe, 1978). The entire volcanic sequence is overlain by Quaternary sediments (Davidson and Rex, 1983).

The NE-SW orientation of the segment of the Omo valley in this area suggests control by preexisting structural weaknesses parallel to the Main Ethiopian Rift (MER) border faults. This possibly indicates earlier location of the rift before it migrated to the east. In addition to this, the E-W alignment of the Wagebeta group of calderas to the east of the MER and the Gojeb river valley and other E-W grabens, represent another set of structures which influenced the architecture of the western margin of the MER and the Omo valley in the study area.

The stress field which produced the two major fault trends (NE-SW and E-W) is also responsible for the frequent occurrence of similarly oriented minor fractures and joints, all of which have significant implications on slope stability conditions in the area.

Dykes and sills excessively intrude the rhyolites which are intercalated with trachytic rocks (Fig. 3). Dolerite dykes and sills and syenite intrusions have been observed in the area. The fracture spacing in most doleritic rocks ranges from $10-50 \mathrm{~cm}$, as observed in the borehole logs (EEPCO, 2004). Thin irregular calcite stringers along planes of weaknesses are also found.

\section{SLOPE STABILITY STUDIES}

In the study area hill slopes are steep and valleys are deep with low vegetation cover. Along the road from Fofa town to powerhouse II, the slope cuts are steep, which overhang at places. Thus, an attempt has been made to analyze the stability condition of potential unstable slopes along the road between Fofa town and Gilgel-Gibe Hydropower II. 


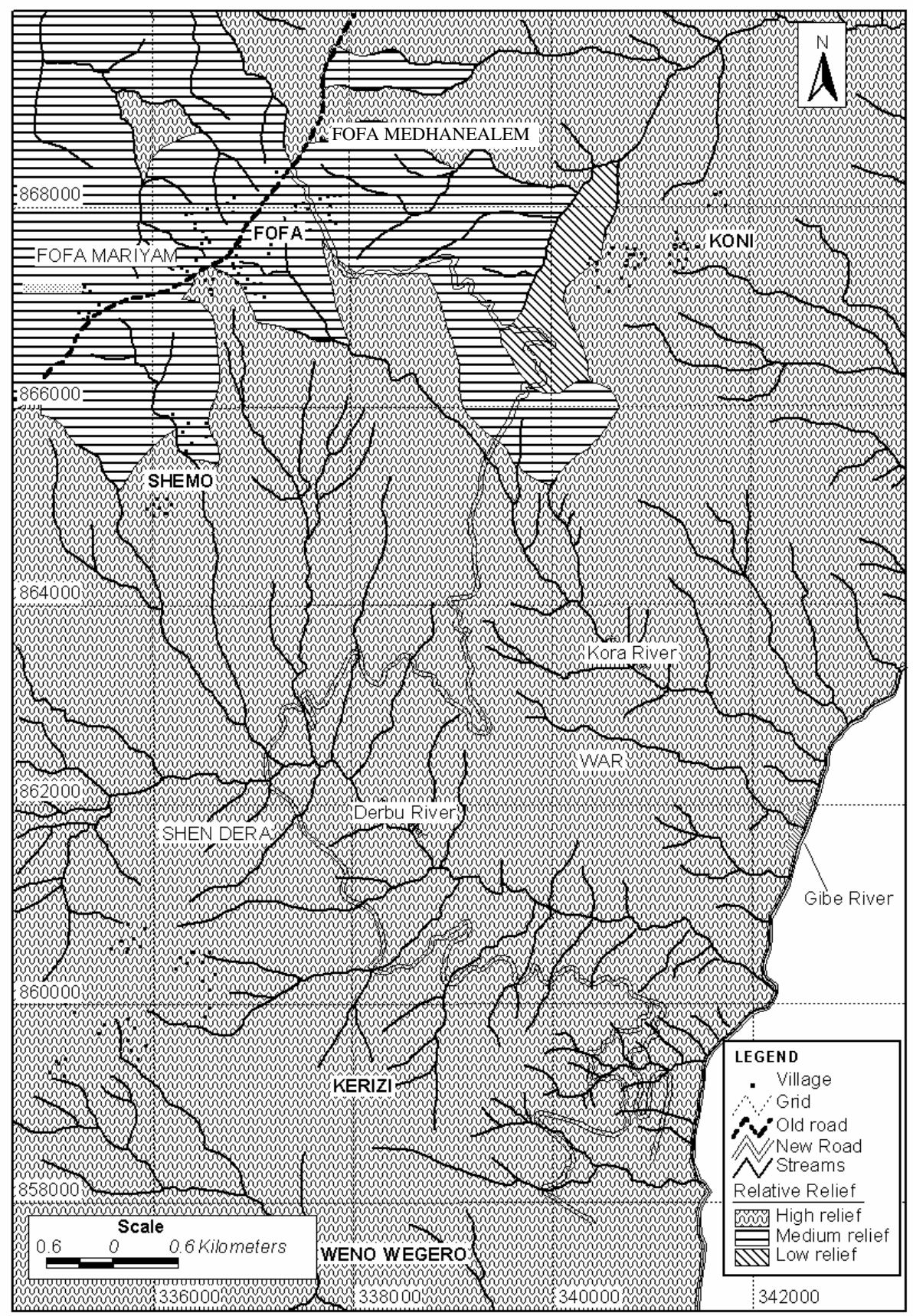

Fig. 2. Relative relief of the study area.

\section{Identification of potential unstable slopes}

A thorough reconnaissance survey was carried out along the newly constructed road. This survey has been carried out mainly to identify the critical slope sections. The critical slope sections have been identified based on their field manifestations of instability, such as i) presence of scarp faces on steep slopes, ii) removal of toe support for road construction, iii) presence of evidences of slope distress, such as, development of tension cracks, bulging of slope face and other such features, and iv) orientation of discontinuities which favour sliding, either on single discontinuity or on a wedge formed by two intersecting discontinuities. Thus, based on the field manifestations of instabilities, eight potentially unstable slopes were identified in the study area (Fig. 4). The detailed stability study of these critical slope sections has been carried out by using limit equilibrium method and is discussed later in this paper. 


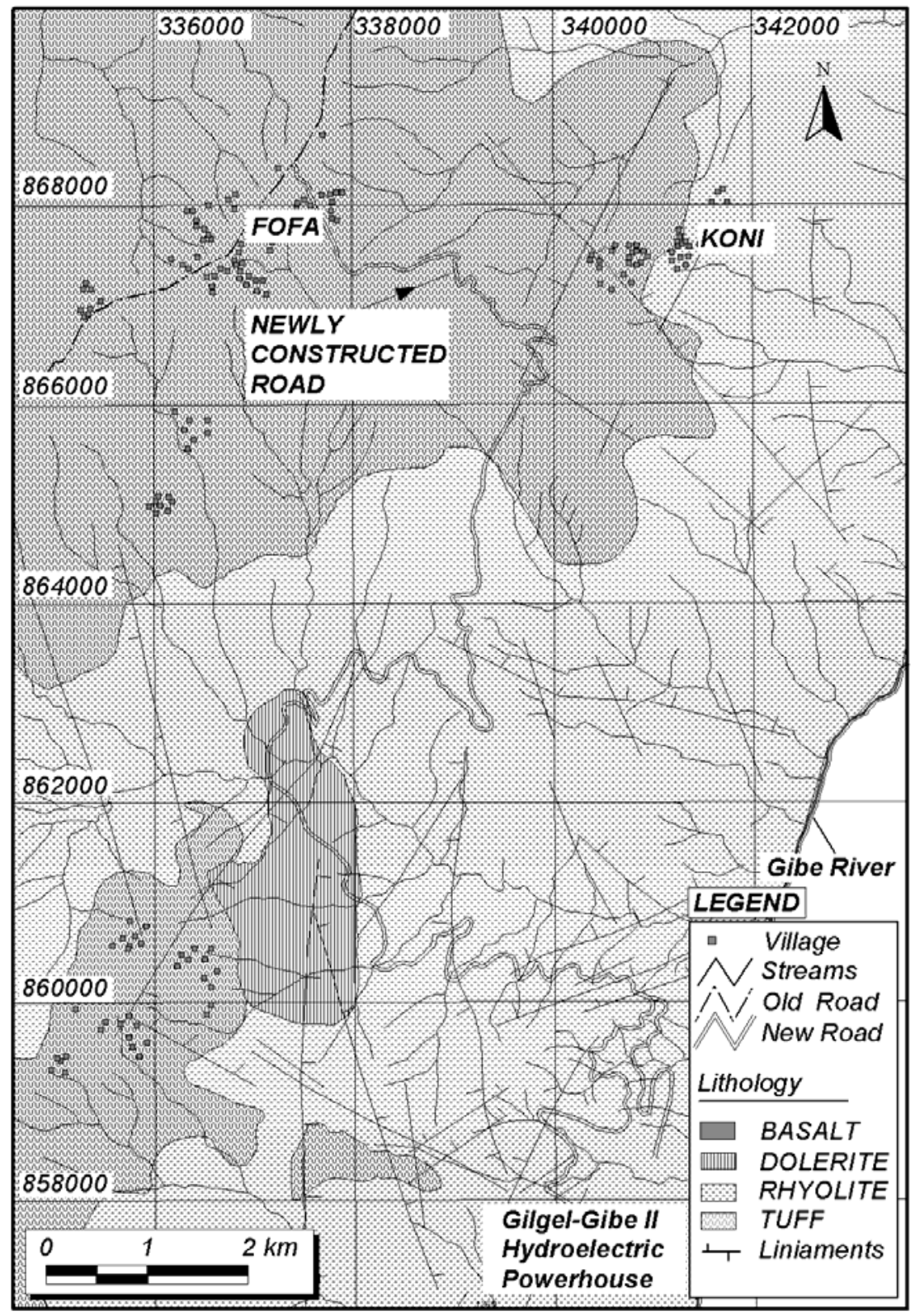

Fig. 3. Geological map of the study area.

\section{Engineering properties of rocks}

For the stability studies the important engineering properties, which have to be considered are the uni-axial compressive strength, unit weight of the rock and the shear strength parameters of the rock along discontinuity planes (Johnson and DeGraff, 1991; Hoek and Bray, 1989).

\section{Laboratory tests}

In order to determine the uniaxial compressive strength (UCS) and the unit weight of the rocks, laboratory tests have been conducted on the representative rock samples collected from each of the exposed rock units. The UCS and unit weight of the rock were determined by ISRM suggested methods (ISRM, 1981). The UCS of rocks were determined by using Schmidt hammer in in-situ condition during the field work, some of the values were also adopted from the project documents. The project authorities conducted UCS tests by following point load tests. Further, the Unit weight of rock in the project area were also determined from laboratory test results, adopted from project report (EEPCO, 2004). The results are presented in Table 1. 


\section{Rock mass quality}

For the present study the rock mass rating system (RMR), proposed by Bieniawiski (1989), has been utilized to work out the shear strength parameters. In order to determine RMR, six basic parameters were used. These are: the uniaxial compressive strength of the rock (UCS), rock quality designation (RQD), spacings of discontinuities, condition of discontinuities, ground water condition and the orientation of discontinuities.



Fig. 4. Identified critical slope sections and locations from where RMR data was collected. 
To work out the rock mass rating (RMR) the uniaxial compressive strength was determined in the laboratory (Table 1). The spacing, separation, roughness, continuity, and orientation of discontinuities and ground water conditions were visually observed/ estimated in the field (Fig. 4). The rock quality designation (RQD) was determined by an empirical relation of Palmstrom (1982). This empirical relation, also known as volumetric count method, is given by Equation (1).

$$
\mathrm{RQD}=115-3.3 \mathrm{Jv}
$$

where, $\mathrm{Jv}$ is the total number of discontinuities greater than $10 \mathrm{~cm}$ in length, in $1 \mathrm{~m}$ cube of exposed rock mass.
For the determination of RMR, all parameters were allocated the importance ratings from the standard table, proposed by Bieniawiski (1989), as shown in Table 2. The table indicates that the rock mass at all critical slope sections falls in poor to very poor rock quality, as the RMR value for all locations fall in the range of 17 to 32 . Further, the shear strength parameters of the rock mass at each critical slope section were determined from RMR (Table 2). These parameters were calculated using the relation of Bieniawiski (1989), which is given by Equations (2) and (3).

$$
\begin{aligned}
& C^{*}=0.05 \mathrm{RMR} \ldots \\
& \phi^{*}=0.5 \mathrm{RMR}+5
\end{aligned}
$$

where; $C^{*}$ and $\phi^{*}$ are cohesion and angle of friction, respectively.

Table 1. Uniaxial compressive strength and unit weight of rocks exposed on critical rock slope sections.

\begin{tabular}{lccc}
\hline Location of samples & Rock type & $\begin{array}{c}\text { Unit weight } \\
\left(\text { ton } \mathrm{m}^{-3}\right)\end{array}$ & $\begin{array}{c}\text { Uniaxial compressive strength } \\
\left(\mathrm{kg} \mathrm{cm}^{-2}\right)\end{array}$ \\
\hline SL1 & Rhyolite & 2.45 & 694 \\
SL2 & Rhyolite & 2.45 & 1387 \\
SL3 & Rhyolite & 2.45 & 989 \\
SL4 & Rhyolite & 2.45 & 1132 \\
SL5 & Rhyolite & 2.45 & 816 \\
SL6 & Dolerite & 2.89 & 1397 \\
SL7 & Rhyolite & 2.45 & 602 \\
SL8 & Rhyolite & 2.45 & 744 \\
\hline
\end{tabular}

a average values.

\begin{tabular}{|c|c|c|c|c|c|c|c|c|c|c|c|c|}
\hline \multirow{3}{*}{$\begin{array}{l}\text { Location of } \\
\text { samples }\end{array}$} & \multicolumn{9}{|c|}{ Parameters (Average ratings) } & \multirow{3}{*}{ RMR } & \multirow{3}{*}{$\begin{array}{l}\text { Angle of } \\
\text { internal } \\
\text { friction } \\
\left.(\phi)()^{\circ}\right)\end{array}$} & \multirow{3}{*}{$\begin{array}{l}\text { Cohesion } \\
(\mathrm{C}) \\
\left(\mathrm{kg} \mathrm{cm}^{-2}\right)\end{array}$} \\
\hline & \multicolumn{2}{|c|}{ UCS } & \multicolumn{3}{|c|}{ RQD } & \multirow[b]{2}{*}{ Sp. } & \multirow[b]{2}{*}{ Con. } & \multirow[b]{2}{*}{ GWC } & \multirow[b]{2}{*}{ Ori. } & & & \\
\hline & UCS & $\mathrm{Ra}$ & Jv. & RQD & Ra. & & & & & & & \\
\hline SL1 & 694 & 7 & 9 & 85 & 17 & 8 & 10 & 13 & -25 & 30 & 20.0 & 1.50 \\
\hline SL2 & 1387 & 12 & 6 & 94 & 17 & 8 & 10 & 10 & -25 & 32 & 21.0 & 1.60 \\
\hline SL3 & 989 & 7 & 9 & 86 & 17 & 8 & 9 & 15 & -25 & 31 & 20.5 & 1.55 \\
\hline SL4 & 1132 & 12 & 10 & 82 & 17 & 10 & 15 & 13 & -50 & 17 & 13.5 & 0.85 \\
\hline SL5 & 816 & 7 & 7 & 92 & 17 & 20 & 10 & 14 & -50 & 18 & 14.0 & 0.90 \\
\hline SL6 & 1397 & 12 & 11 & 78 & 17 & 15 & 15 & 15 & -50 & 24 & 17.0 & 1.20 \\
\hline SL7 & 602 & 7 & 9 & 87 & 17 & 20 & 15 & 12 & -50 & 21 & 15.5 & 1.05 \\
\hline SL8 & 744 & 7 & 7 & 93 & 17 & 20 & 15 & 13 & -50 & 22 & 16.0 & 1.12 \\
\hline
\end{tabular}

Table 2. Rock mass classification and estimated shear strength parameters for rock mass at critical rock slope sections.

UCS, uniaxial compressive strength; Ra, rating; Jv, volumetric count; RQD, rock quality designation; Sp., spacing of discontinuity; Con., condition of discontinuity; GWC, ground. 


\section{Discontinuity analysis}

Discontinuities are the structural weakness planes along which movement of rock mass can take place. The presence or absence of discontinuities has a very important influence upon the stability of rock slopes and the detection of these geological features is the most critical part of the stability investigation (Hoek and Bray, 1989). The rock mass exposed on the critical slope sections in the study area is traversed by discontinuity planes mainly, joints, faults, and dykes. Structural data on preferred orientations of these discontinuity planes have been collected from all critical rock slope sections. For each discontinuity plane the azimuth of the 'dip-direction' clockwise in relation to magnetic north from $0^{\circ}$ to $360^{\circ}$, has been measured, whereas amount of dip was measured along its true dip direction in the plane. Later, the data has been analyzed using Spheristat 2.0 and Microdem computer programs. The poles were then plotted on a Schmidt projection, lower hemisphere. Using the density analysis facility of the program, the poles were contoured on 'Schmidt' counting net. Thus, the preferred orientations of discontinuity planes were determined. Further, the major planes, dip directions and dips were plotted in Microdem computer program, which were later utilized for the Kinematic check to determine the possible mode of failure. Figure 5 and Table 3 present the preferred orientations, as observed on various critical rock slope sections in the study area (Figs 6 and 7).
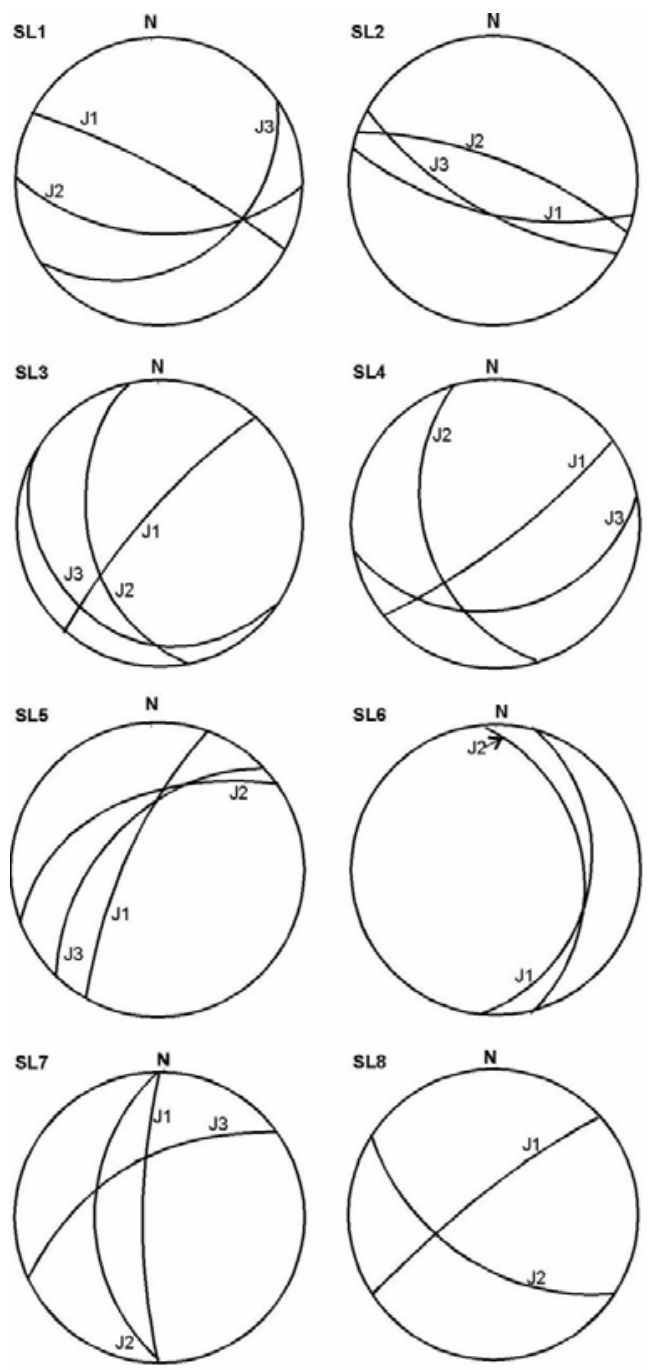

Fig. 5. Preferred orientation of discontinuity planes on various critical rock slope sections.

Table 3. Preferred orientation of discontinuity planes, geometry of slope and possible mode of failure in critical slope sections.

\begin{tabular}{|c|c|c|c|c|c|c|c|}
\hline \multirow{2}{*}{$\begin{array}{l}\text { Slope } \\
\text { section }\end{array}$} & \multicolumn{3}{|c|}{ Geometry of the critical slope } & \multicolumn{3}{|c|}{$\begin{array}{l}\text { Preferred orientation of discontinuity } \\
\text { planes (Dip Direction/ Dip Amount) }\end{array}$} & \multirow{2}{*}{$\begin{array}{l}\text { Possible mode of } \\
\text { failure }\end{array}$} \\
\hline & $\begin{array}{c}\text { Slope/inclination } \\
\left({ }^{\circ}\right)\end{array}$ & $\begin{array}{l}\text { Upper Slope/ } \\
\text { inclination }\left({ }^{\circ}\right)\end{array}$ & $\mathrm{H}(\mathrm{m})$ & $\mathrm{J} 1\left(^{\circ}\right)$ & $\mathrm{J} 2\left(^{\circ}\right)$ & $\mathrm{J} 3\left(^{\circ}\right)$ & \\
\hline SL1 & $\mathrm{N} 170 / 75$ & N 170/17 & 12 & N028/83 & N 182/63 & N 145/41 & Planar (J3)* \\
\hline SL2 & N 210/74 & $\mathrm{N} 210 / 20$ & 15 & $\mathrm{~N} 193 / 72$ & N021/77 & $\mathrm{N} 216 / 59$ & Planar (J3) \\
\hline SL3 & N 335/76 & N 335/15 & 18 & N312/82 & $\mathrm{N} 258 / 49$ & $\mathrm{~N} 213 / 21$ & Planar (J3) \\
\hline SL4 & N $185 / 78$ & N $185 / 26$ & 15 & $\mathrm{~N} 139 / 75$ & $\mathrm{~N} 253 / 49$ & $\mathrm{~N} 169 / 39$ & Planar (J3) \\
\hline SL5 & N 315/60 & N $315 / 24$ & 18 & $\mathrm{~N} 297 / 77$ & N356/54 & $\mathrm{N} 316 / 40$ & Planar (J3) \\
\hline SL6 & N 080/57 & N 080/20 & 19 & $\mathrm{~N} 100 / 42$ & N080/46 & -- & Planar (J2) \\
\hline SL7 & N 270/72 & N 270/27 & 11 & $\mathrm{~N} 270 / 85$ & $\mathrm{~N} 269 / 54$ & N326/60 & Planar (J2) \\
\hline SL8 & N 270/67 & N 270/32 & 10 & $\mathrm{~N} 318 / 82$ & $\mathrm{~N} 213 / 61$ & -- & Wedge (J1, J2) \\
\hline
\end{tabular}

* Potential failure plane/s. 


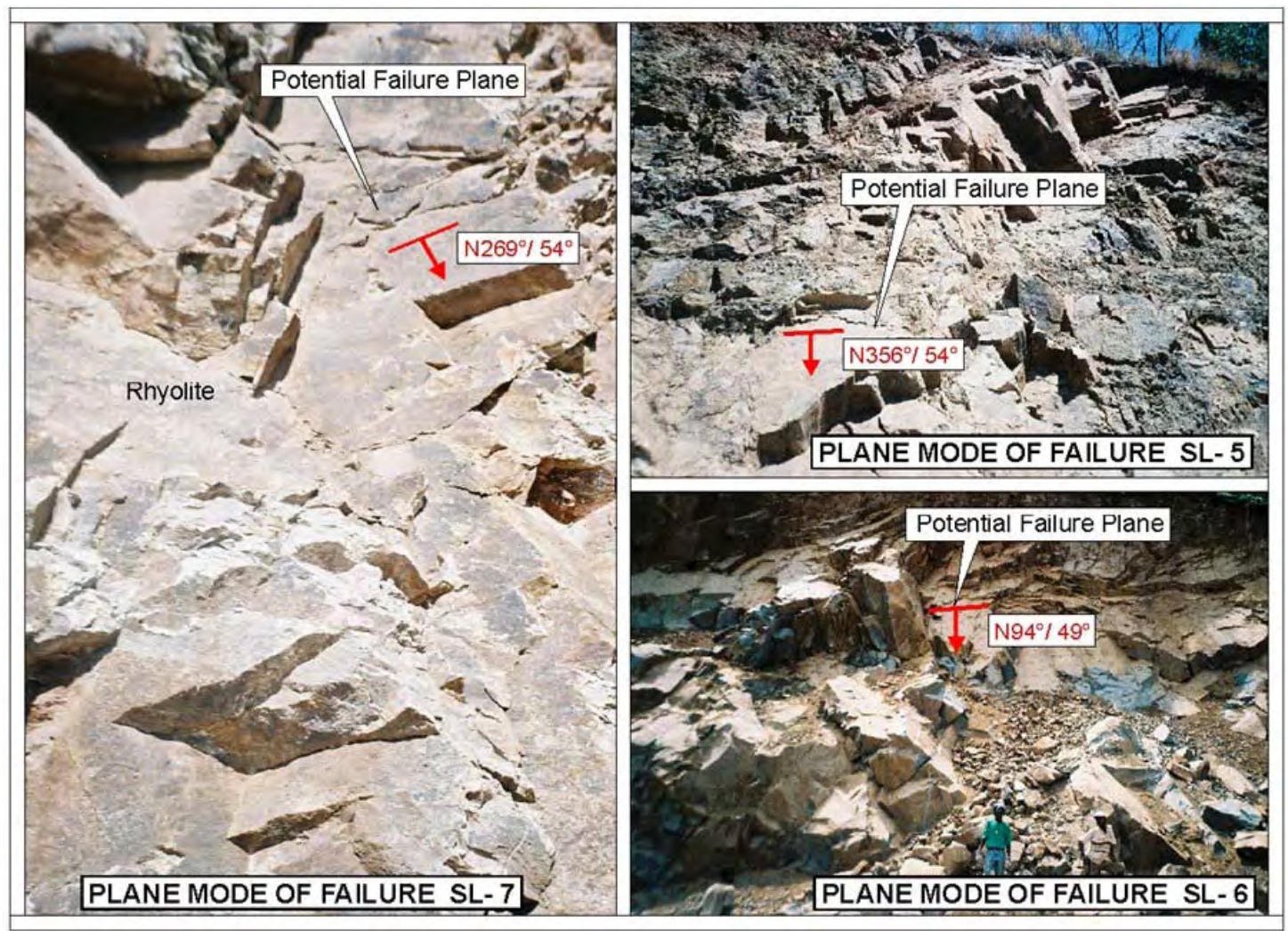

Fig. 6. Possible plane mode of failure in rock mass (Slope section SL 5, SL6 and SL7)

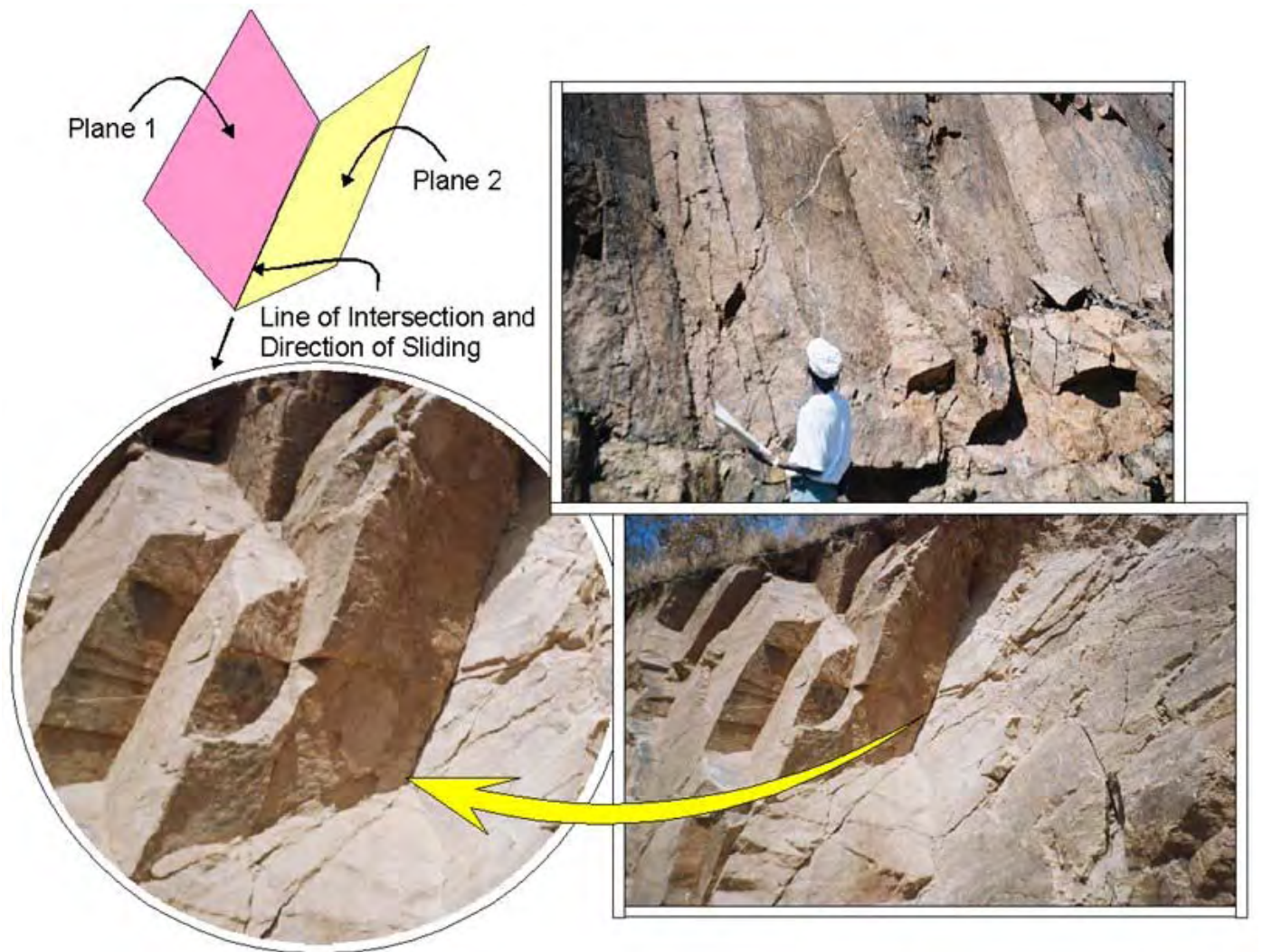

Fig. 7. Wedge Mode of Failures along the road cut (Slope section SL8). 
Geometry and geology of the critical slope sections

For the detailed stability analysis, cross sections have been prepared along all critical slopes. The geometry of slope sections in terms of slope direction and inclination, upper slope direction, inclination and the height of the slope are presented in Figure 8 and Table 3.
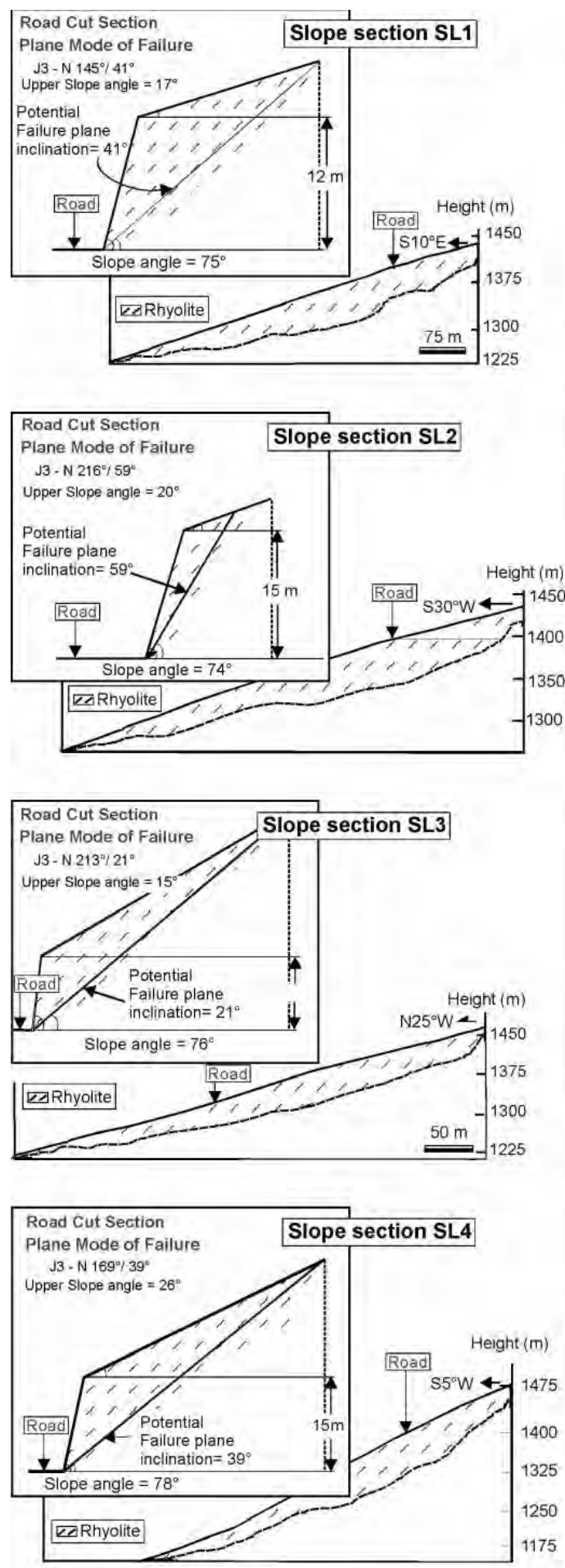

Geological cross sections have been prepared along all the critical slope sections. The geological details for these cross sections were observed along the road cut and the natural outcrops. Further, the geological cross sections described in the technical report (EEPCO, 2004) have also been utilized.
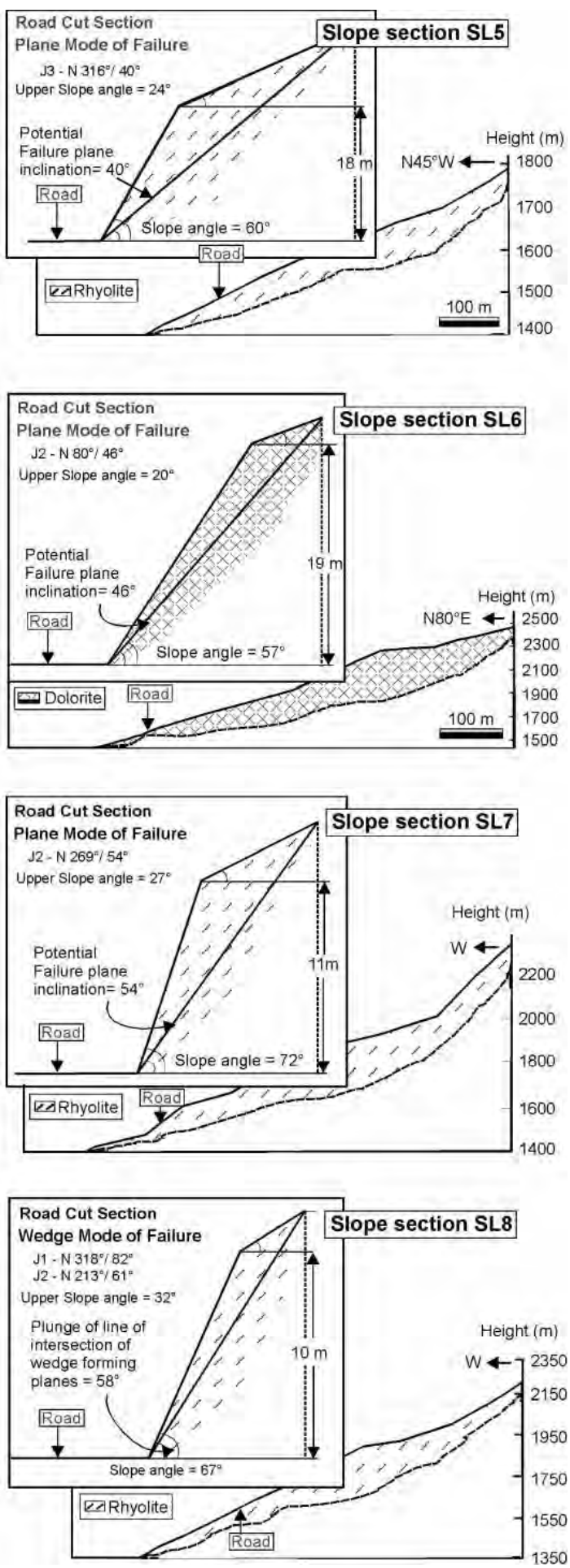

Fig. 8. Geology and geometry of the critical slope sections. 


\section{Kinematic check}

For the kinematics check, Markland test (Johnson and DeGraff, 1991; Hoek and Bray, 1989; Yoon et al., 2002) has been applied to all critical rock slope sections. Structural data, along with slope inclination and a 'pi circle' corresponding to angle of friction $(\phi)$ of the rock mass has been plotted on equal area projection 'Schmidt Net'. The angle of friction has been estimated from RMR data (Table 2). Figure 9 presents the stereo plots showing possible modes of failure in critical rock slope sections. It has been found that, out of a total eight critical rock slope sections seven slope sections satisfy the condition for plane mode of failure, whereas one slope section (SL8) satisfies the condition for wedge mode of failure. Thus, these slopes have been further analyzed for factor of safety (FoS) under existing and anticipated worst conditions. Table 3 presents the possible modes of failures in critical slope sections in the study area.

\section{Estimation of shear strength parameters for the} discontinuities

For the stability analysis of rock slopes, shear strength properties of the rock mass along potential discontinuity planes are important parameters (Hoek and Bray, 1989; Johnson and DeGraff, 1991; Sharma et al., 1999). Thus, an attempt was made to estimate the shear strength of these joint sets. Due to the non-availability of the cores through these joint sets, the shear strength of these joint surfaces was estimated using the empirical law of friction for rock joints, which can be used for extrapolating and predicting shear strength data (Barton, 1973).

\section{Limit equilibrium analysis for critical slope sections}

Limit equilibrium method of analyzing stability of rock slopes is an effective and efficient method to quantitatively assess the stability condition of a slope (Hoek and Bray, 1989). For limit equilibrium method factor of safety has to be determined. The various forces involved in the stability condition of a rock slope are weight of the sliding rock mass over a failure plane or on two intersecting discontinuity planes, cohesive force on the discontinuity plane/s, uplift water forces acting along the discontinuity plane and the vertical water force acting on the back face of the tension crack (Hoek and Bray, 1989).
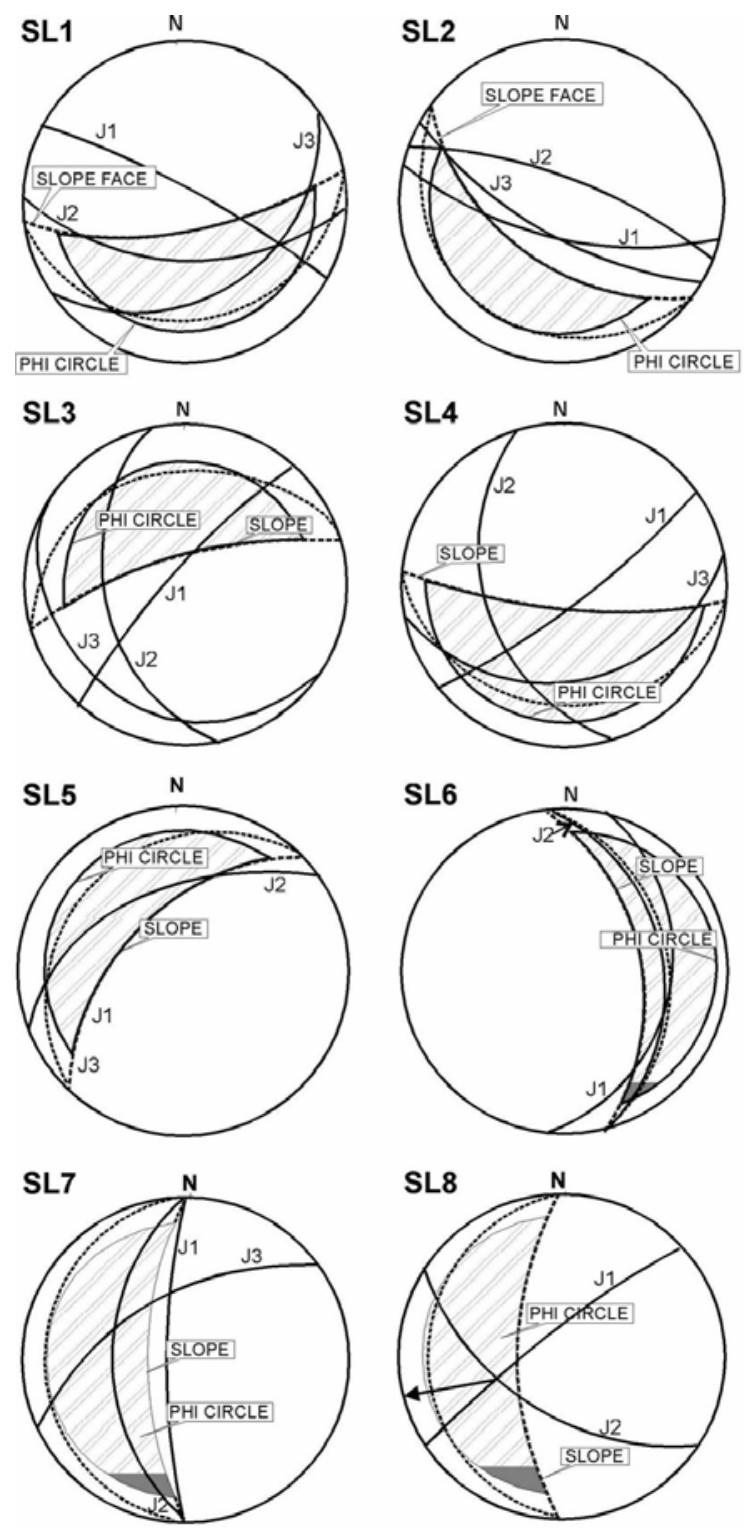

Fig. 9. Stereo plots showing possible mode of failure in critical rock slope sections.

Factor of safety (FoS) is the ratio of the total force available to resist sliding to the total force tending to induce sliding (Hoek and Bray, 1989; Price, 2009). For the present study, for all critical slope sections the factor of safety has been determined for static and dynamic conditions under varying water saturation situations. The factor of safety has been determined for existing and possible worst conditions, represented by the following conditions;

i) Static dry condition - when slope is not subjected to any water saturation and static conditions prevail. 
ii) Static moderately saturated condition when the slope is subjected to moderate saturation; this condition may occur during moderate rains and static conditions prevail.

iii) Static fully saturated condition - when the slope is subjected to full saturation, which may occur during very heavy rains and static conditions prevail.

iv) Dynamic dry condition - when slope is not subjected to any water saturation and earthquake occurs.

v) Dynamic moderately saturated condition when the slope is subjected to moderate saturation; this condition may occur during moderate rains and earthquake occurs.

vi) Dynamic fully saturated condition - when the slope is subjected to full saturation, this condition may occur during very heavy rains and earthquake occurs.

Out of the 6 conditions mentioned above, the condition that prevailed at the time of investigation is represented by static dry condition. The possible anticipated worst condition is presumed to be represented by dynamic moderately saturated condition. However, the FoS has been determined for all possible anticipated conditions.

\section{Planar mode of failure analysis}

Planar failure occurs when the strike of the discontinuity plane is nearly parallel to the strike of the slope and it daylights on the slope face (Hoek and Bray, 1989; Sharma et al., 1995; Sharma et al., 1999). For the present study in total seven critical slope sections satisfy the Markland condition for planar mode of failure. The analysis has been carried out by plane failure analysis technique of Sharma et al. (1995). These critical slope sections have been analyzed for factor of safety (FoS) under static and dynamic conditions for varying water saturation situations. The saturation conditions were represented by dry slope, tension cracks half filled and tension crack completely filled with water. Figure 10 shows the geometry of slope and various force vectors involved in the analysis. For the plane failure analysis, the following assumptions have been made (Sharma et al., 1995).

i) For saturated condition, the tension crack is fully filled with water. The water in the tension crack seeps along the failure surface and escapes out on the slope face through the sliding plane, where it daylights on the slope face.

ii) There is no resistance to sliding on the lateral boundaries of the sliding rock mass.

iii) For moderately saturated condition the tension crack $\left(Z_{\mathrm{L}}\right)$ is half filled and the water level in the crack $Z_{\mathrm{w}}=0.5 \mathrm{Z}_{\mathrm{L}}$ (Fig. 10). The water in the tension crack seeps along the failure surface and escapes out on the slope face through the sliding plane, day lighting on the slope face.

iv) For dry condition, the rock mass is completely dry $\left(Z_{w}=0\right)$.

v) The upper slope inclination must be less than the inclination of the failure plane $\left(\alpha_{s}\right.$ $<\alpha_{\mathrm{p}}$ ).

The Fos for static condition is determined by Equation (4).

$$
F=\frac{C A+\left(W \cos \alpha_{p}-U-V \sin \alpha_{p}\right) \tan \phi}{W \sin \alpha_{p}+V \cos \alpha_{p}}
$$

where, $\mathrm{F}=$ factor of safety;

$\mathrm{C}=$ cohesion;

$\mathrm{A}=$ area of the sliding block;

$\mathrm{W}=$ weight of the sliding mass;

$\alpha_{p}=$ failure plane inclination;

$\mathrm{U}=$ uplift water force acting along the failure plane;

$\mathrm{V}=$ vertical water force acting at the rear face of the tension crack and $\varphi=$ angle of friction.

The Fos for dynamic condition is determined by Equation (5).

$$
F=\frac{C A+\left[W\left(\cos \alpha_{p}-\alpha \sin \alpha_{p}\right)-U-V \sin \alpha_{p}\right] \tan \phi}{W\left(\sin \alpha_{p}+\alpha \cos \alpha_{p}\right)+V \cos \alpha_{p}} \ldots
$$

where; $\alpha$ is the horizontal earthquake acceleration.

As per the technique of plane failure analysis (Sharma et al., 1995) the area, weight, horizontal water forces and uplift water forces were calculated.

Seismically, the study area falls in MM intensity scale 7 (Laike Mariam Asfaw, 1986). The horizontal acceleration for MM intensity 7 will fall in $0.07 \mathrm{~g}$ to $0.1 \mathrm{~g}$ (Johnson and Degraff, 1991). An average value of $0.08 \mathrm{~g}$ has been considered for the present analysis. 


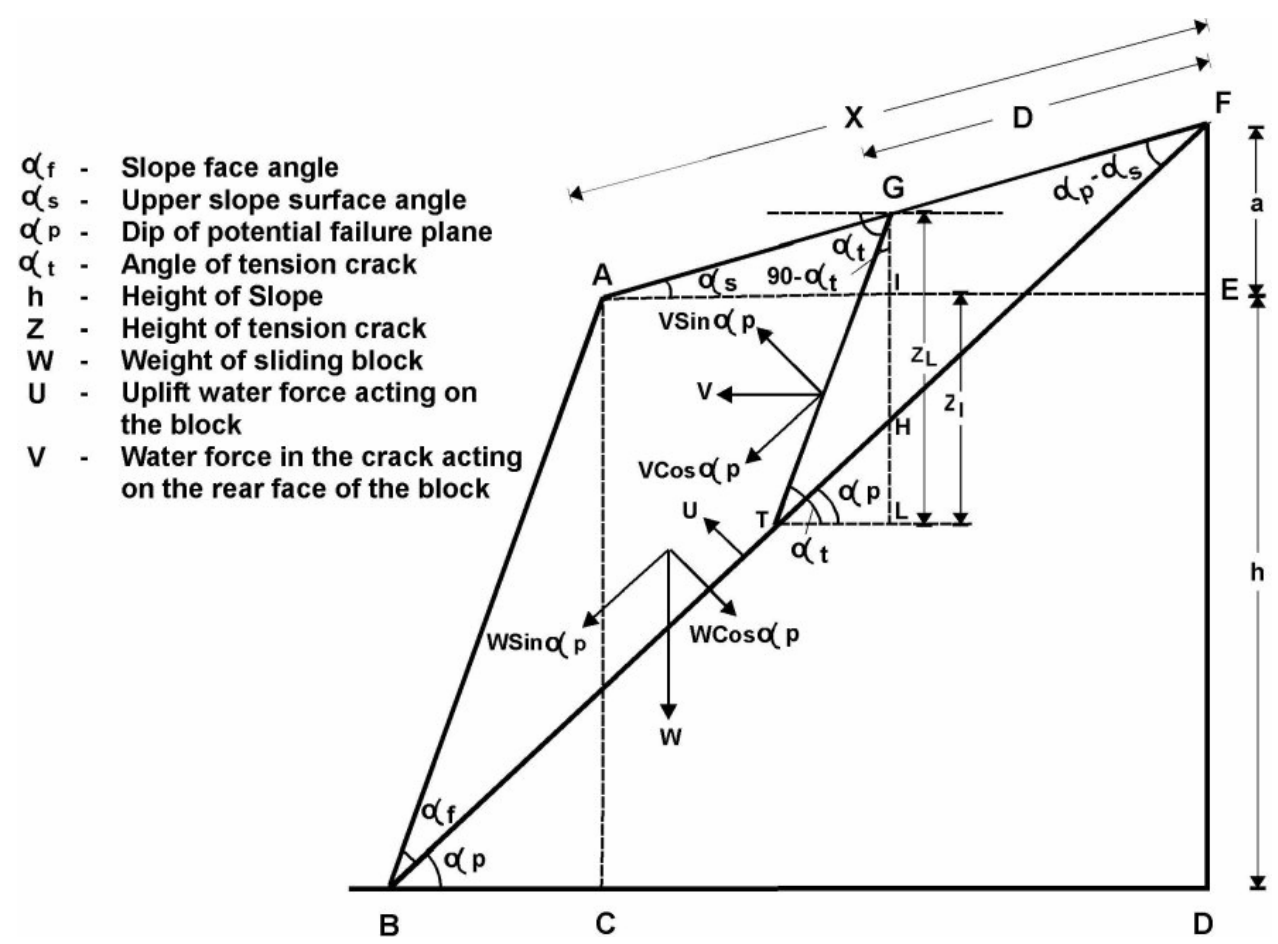

Fig. 10. Geometry and force vectors considered in plane failure analysis.

For all critical slope sections, the geometry of the slope (slope angle, upper slope angle, height) has been derived from the cross section prepared from 1:50,000 topographical map and for road cut geometry the sections at 1:350, in the project technical report (EEPCO, 2004) has been used (Fig. 8).

In order to estimate the angle of friction $(\phi)$ for the potential failure planes the law of friction (Barton, 1973) has been applied. Inspection of Table 4 indicates that the estimated values of angle of friction are on the higher side. In view of the larger persistence of joints, slickensided to slightly rough and moderately weathered surfaces, the values estimated using the law of friction (Barton, 1973) may not represent the realistic condition. Moreover, the angle of internal friction of the rock mass at all critical slope sections, as derived from RMR, is much lower (Table 2) than what is estimated using the law of friction. Therefore, to be on conservative side, the angle of friction $(\phi)$ estimated by RMR has been considered for the stability analysis.

Table 4. Estimated Shear strength of rock mass along potential discontinuity planes at various critical slope Sections.

\begin{tabular}{|c|c|c|c|c|c|c|c|}
\hline $\begin{array}{l}\text { Slope } \\
\text { Section }\end{array}$ & $\begin{array}{l}\text { Potential } \\
\text { Joint Plane }\end{array}$ & $\begin{array}{c}\text { Basic } \\
\text { friction } \\
\text { angle }\left(^{\circ}\right)\end{array}$ & $\begin{array}{c}\text { Joint } \\
\text { roughness } \\
\text { coefficient } \\
(J R C)^{*}\end{array}$ & $\begin{array}{c}\mathrm{JCS}^{\mathrm{a}} \\
\left(\mathrm{kg} \mathrm{cm}^{-2}\right)\end{array}$ & $\begin{array}{l}\text { Compressive } \\
\text { strength of } \\
\text { unweathered } \\
\text { rock surfaces } \\
\left(\mathrm{kg} \mathrm{cm}^{-2}\right)\end{array}$ & $\begin{array}{c}\text { Effective } \\
\text { normal stress } \\
\text { acting on } \\
\text { joint surface } \\
\left(\mathrm{kg} \mathrm{cm}^{-2}\right)\end{array}$ & $\begin{array}{l}\text { Angle } \\
\text { of } \\
\text { friction } \\
\text { Tan }^{-1} \\
\left(\tau / \sigma_{n}\right) \\
\end{array}$ \\
\hline SL1 & $\mathrm{J} 3,\left(\mathrm{~N} 145^{\circ} / 41^{0}\right)$ & 30 & 4 & 173.5 & 694 & 0.64 & 39.70 \\
\hline SL2 & $\mathrm{J} 3,\left(\mathrm{~N} 216^{0} / 5^{\circ}\right)$ & 30 & 5 & 346.75 & 1387 & 0.25 & 45.70 \\
\hline SL3 & $\mathrm{J} 3,\left(\mathrm{~N} 213^{\circ} / 21^{0}\right)$ & 30 & 4 & 247.25 & 989 & 1.73 & 38.60 \\
\hline SL4 & $\mathrm{J} 3,\left(\mathrm{~N} 169^{\circ} / 3^{\circ}\right)$ & 30 & 6 & 283 & 1132 & 0.92 & 44.90 \\
\hline SL5 & $\mathrm{J} 3,\left(\mathrm{~N} 316^{\circ} / 40^{\circ}\right)$ & 30 & 4 & 204 & 816 & 0.66 & 39.96 \\
\hline SL6 & $\mathrm{J} 2,(\mathrm{~N} 800 / 460)$ & 32 & 2 & 349.25 & 1397 & 0.43 & 37.80 \\
\hline SL7 & $\mathrm{J} 2$, (N 690/540) & 30 & 5 & 150.5 & 602 & 0.25 & 43.89 \\
\hline
\end{tabular}

* JRC as determined by roughness profile chart proposed by Barton and Choubey (1977).

' $a$ '= Joint compressive strength. 
It is presumed that tension crack will develop along any pre existing discontinuity plane, which dips more or less in the same direction as the failure plane, thus accordingly the inclination of tension crack is derived. The input parameters used for the determination of factor of safety for plane failure analysis of critical slope sections is presented in Table 5. The factor of safety has been calculated for static and dynamic conditions for varied water saturation situations (Table 6 and Fig. 11).

Inspection of Table 6 and Figure 11 indicates that for the existing conditions (static and dry) slope sections SL2 and SL7 are stable. The remaining slope sections are unstable for existing and anticipated adverse conditions (FoS < 1.0). The stability of slope section SL3 under static condition would be critically stable. However, for the anticipated worst condition (dynamic and moderate saturation) all seven slope sections would be unstable, except slope section SL2 (FoS = 1.45). Therefore, there is a need to provide remedial measures to the slope sections, which have a FoS less than 1.0 for the anticipated adverse conditions. The slope section, which shows Fos less than 1.0, is likely to fail under the given condition. Therefore, there is a need to improve the stability condition of such slopes by means of suitable remedial measures. The slope design and other remedial measures are discussed later in this paper.

\section{Wedge mode of failure analysis}

Wedge mode of failure occurs when two structural discontinuity planes strike obliquely and their line of intersection in the direction of the slope face. The sliding of rock mass will be on these two intersecting planes in the direction in which the line of intersection plunges. For the wedge failure to occur, the kinematic condition defined as $\alpha_{\mathrm{f}}>\alpha_{\mathrm{i}}>\phi$ has to be satisfied. Where; $\alpha_{\mathrm{f}}$, is the inclination of the slope face; $\alpha_{\mathrm{i}}$, is the plunge of the line of intersection of the two wedge forming planes and $\phi$, is the angle of friction (Hoek and Bray, 1989).

Table 5. Input parameters for determination of factor of safety for critical slopes having plane mode of failure.

\begin{tabular}{|c|c|c|c|c|c|c|c|c|c|c|}
\hline $\begin{array}{l}\text { Slope } \\
\text { Section }\end{array}$ & $\begin{array}{l}\text { Slope } \\
\text { angle } \\
\left(\alpha_{\mathrm{f}}\right)\left(^{\circ}\right)\end{array}$ & $\begin{array}{l}\text { Upper } \\
\text { Slope } \\
\text { angle } \\
\left(\alpha_{\mathrm{s}}\right)\left(^{\circ}\right)\end{array}$ & $\begin{array}{l}\text { Failure } \\
\text { Plane } \\
\text { angle } \\
\left(\alpha_{p}\right)\left(^{\circ}\right)\end{array}$ & $\begin{array}{l}\text { Tension } \\
\text { Crack } \\
\text { angle } \\
\left(\alpha_{\mathrm{t}}\right)\left(^{\circ}\right)\end{array}$ & $\begin{array}{l}\text { Cohesion } \\
(\mathrm{C}) \\
\left(\text { ton } \mathrm{m}^{-2} \text { ) }\right.\end{array}$ & $\begin{array}{l}\text { Angle of } \\
\text { Friction } \\
(\phi)\left(^{\circ}\right)\end{array}$ & $\begin{array}{c}\text { Density } \\
\text { of Rock } \\
\quad(\gamma) \\
\left(\text { ton } \mathrm{m}^{-3}\right)\end{array}$ & $\begin{array}{c}\text { Unit } \\
\text { weight of } \\
\text { Water }\left(\gamma_{\mathrm{w}}\right) \\
\left(\text { ton } \mathrm{m}^{-3}\right)\end{array}$ & $\begin{array}{l}\text { Horizontal } \\
\text { Earthquake } \\
\text { Acceleration } \\
\qquad(\alpha)\end{array}$ & $\begin{array}{l}\text { Height } \\
\text { (H) } \\
\text { (m) }\end{array}$ \\
\hline SL1 & 75 & 17 & 41 & 63 & 15.0 & 20.0 & 2.45 & 1.0 & $0.08 \mathrm{~g}$ & 12 \\
\hline SL2 & 74 & 20 & 59 & 90 & 16.0 & 21.0 & 2.45 & 1.0 & $0.08 \mathrm{~g}$ & 15 \\
\hline SL3 & 76 & 15 & 21 & 90 & 15.5 & 20.5 & 2.45 & 1.0 & $0.08 \mathrm{~g}$ & 18 \\
\hline SL4 & 78 & 26 & 39 & 90 & 8.5 & 13.5 & 2.45 & 1.0 & $0.08 \mathrm{~g}$ & 15 \\
\hline SL5 & 60 & 24 & 40 & 77 & 9.0 & 14.0 & 2.45 & 1.0 & $0.08 \mathrm{~g}$ & 18 \\
\hline SL6 & 57 & 20 & 46 & 83 & 12.0 & 17.0 & 2.89 & 1.0 & $0.08 \mathrm{~g}$ & 19 \\
\hline SL7 & 72 & 27 & 54 & 85 & 10.5 & 15.5 & 2.45 & 1.0 & $0.08 \mathrm{~g}$ & 11 \\
\hline
\end{tabular}

Table 6. Stability condition of critical slopes having planar mode of failure.

\begin{tabular}{lcccccc}
\hline & \multicolumn{5}{c}{ Factor of safety (FoS) } \\
\cline { 2 - 7 } Slope Section & \multicolumn{7}{c}{ Static condition } & \multicolumn{3}{c}{ Dynamic condition } \\
\cline { 2 - 7 } & Dry & Moderately Saturated & Fully Saturated & Dry & Moderately Saturated & Fully Saturated \\
\hline SL1 & 0.42 & 0.35 & 0.16 & 0.36 & 0.28 & 0.13 \\
SL2 & 1.67 & 1.54 & 1.31 & 1.57 & 1.45 & 1.23 \\
SL3 & 1.06 & 1.04 & 1.00 & 0.85 & 0.84 & 0.81 \\
SL4 & 0.44 & 0.42 & 0.38 & 0.38 & 0.36 & 0.33 \\
SL5 & 0.62 & 0.58 & 0.52 & 0.56 & 0.51 & 0.46 \\
SL6 & 0.38 & 0.38 & 0.37 & 0.33 & 0.33 & 0.32 \\
SL7 & 1.19 & 1.22 & 1.07 & 1.21 & 1.13 & 0.91 \\
\hline
\end{tabular}




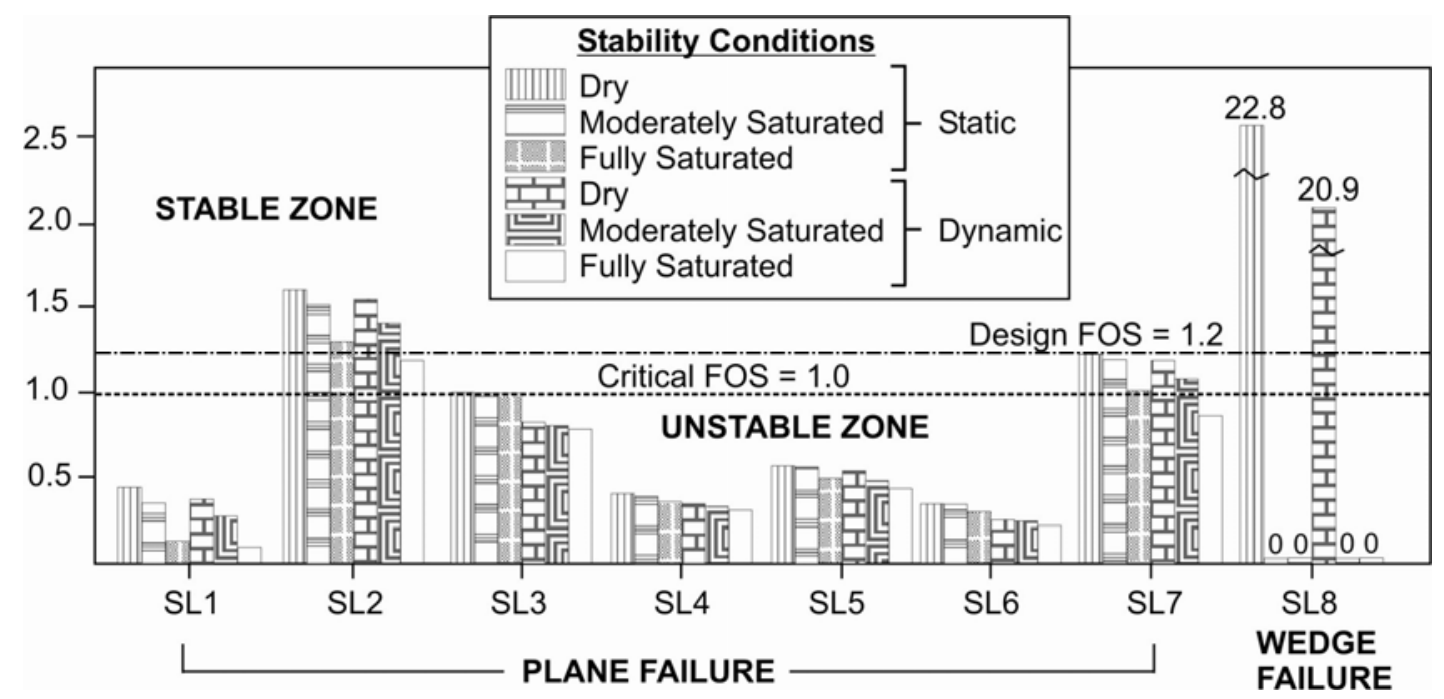

Fig. 11. Stability condition of critical slope sections for existing and anticipated worst conditions.

In the study area one-slope section, SL8 satisfies the kinematic condition for wedge mode of failure (Fig. 9). The two discontinuity planes involved in this slope section are $\mathrm{J} 1$ and $\mathrm{J} 2$ which have orientations $\mathrm{N} 318^{\circ} / 82^{\circ}$ and $\mathrm{N} 213^{\circ} / 61^{\circ}$, respectively. The plunge of the line of intersection is oriented $\mathrm{N} 232^{\circ} / 58^{\circ}$. Thus, detailed stability analysis for this slope has been carried out for static and dynamic conditions under varied water saturation situations.

In order to calculate the factor of safety of SL8 slope section, the computer program 'SASW' (Singh and Goel, 2002) has been used. This computer program is based on the "Comprehensive Solution for wedge failure" proposed by Hoek and Bray (1989). The input parameters required for 'SASW' are the number of slope, number of joint sets, number of cases, dip of the $\mathrm{I}^{\text {th }}$ joint plane $\left(^{\circ}\right), \mathrm{C}(\mathrm{I})$, cohesion of $\mathrm{I}^{\text {th }}$ joint plane $\left(\right.$ ton $\left.\mathrm{m}^{-2}\right), \phi$, friction angle of $\mathrm{I}^{\text {th }}$ joint plane $\left(^{\circ}\right)$, upper slope surface angle, dip direction of the upper slope surface, angle of rock slope, dip direction of the rock slope, height of the crest of the slope above toe of intersection, $\gamma_{r}$, unit weight of the rock, $\gamma_{\mathrm{w}}$, unit weight of water, $\alpha$, coefficient of horizontal acceleration near the crest of the slope, corresponding earth quake magnitude and pore water pressure factor.

The various input parameter used for the analysis of Slope SL8 are:

i) Dip and dip direction of two wedge forming planes, have been derived after analyzing the structural discontinuity data for their preferred orientation (Fig. 5). ii) Slope geometry i.e., slope inclination, upper slope inclination and the height of the slope, obtained after preparing a slope cross section from topographical map on 1:50,000 and for road cut procuring cross section on 1:350 scale from the technical document (EEPCO, 2004). The geometry of slope SL8 is shown in Figure 8.

iii) The shear strength parameters, cohesion (C) and angle of friction ( $\phi)$ have been derived from RMR data collected from the field (Table 2).

iv) The horizontal earthquake acceleration $(\alpha)$ has been taken as $0.08 \mathrm{~g}$. The derivation of ' $\alpha$ ' has already been explained in the previous paragraph.

The input data sheet for critical slope section SL8 is given in Table 7. The factor of safety has been calculated for static and dynamic conditions for varied water saturation situations (Table 8 and Fig. 11).

Examination of Table 8 indicates that the road cut slope section is stable for the existing condition (static dry) and will remain stable even for dynamic condition when it is dry. However, the entire slope section (SL8) is not stable for existing and other anticipated conditions. For anticipated worst condition (dynamic moderately saturated) both road cut slope section and the entire slope (SL8) will be unstable (FoS<1.0). Therefore, there is a need to design suitable remedial measures for this slope section so that it will remain stable for the anticipated worst conditions. 
Table 8. Stability condition of critical slope having wedge mode of failure.

\begin{tabular}{|c|c|c|c|c|c|c|c|}
\hline \multirow{3}{*}{\multicolumn{2}{|c|}{ Slope Section }} & \multicolumn{6}{|c|}{ Factor of safety } \\
\hline & & \multicolumn{3}{|c|}{ Static Condition } & \multicolumn{3}{|c|}{ Dynamic Condition } \\
\hline & & Dry & $\begin{array}{c}\text { Moderately } \\
\text { Saturated }\end{array}$ & $\begin{array}{c}\text { Fully } \\
\text { Saturated }\end{array}$ & Dry & $\begin{array}{c}\text { Moderately } \\
\text { Saturated }\end{array}$ & $\begin{array}{c}\text { Fully } \\
\text { Saturated }\end{array}$ \\
\hline \multirow{2}{*}{ SL8 } & Road Cut Slope & 22.8 & $<1$ & $<1$ & 20.9 & $<1$ & $<1$ \\
\hline & Entire Slope & 0.57 & $<1$ & $<1$ & 0.56 & $<1$ & $<1$ \\
\hline
\end{tabular}

Table 7. Input data sheet for wedge failure analysis for SL8 slope section.

\begin{tabular}{|c|c|c|c|}
\hline \multicolumn{2}{|c|}{ Input parameters } & \multirow{2}{*}{$\begin{array}{c}\text { Road Cut Section } \\
\text { N318 }\end{array}$} & \multirow{2}{*}{$\begin{array}{c}\text { Entire Slope Section } \\
\text { N318 }\end{array}$} \\
\hline & Dip Direction $\left({ }^{\circ}\right)$ & & \\
\hline Plane 1 & Amount $\left({ }^{\circ}\right)$ & 82 & 82 \\
\hline \multirow{2}{*}{ Plane 2} & Dip Direction $\left({ }^{\circ}\right)$ & N213 & N213 \\
\hline & Amount $\left({ }^{\circ}\right)$ & 61 & 61 \\
\hline \multirow{2}{*}{$\begin{array}{l}\text { Upper Slope } \\
\text { Surface }\end{array}$} & Direction (o) & N270 & N270 \\
\hline & Inclination $\left(^{\circ}\right)$ & 32 & 32 \\
\hline \multirow{2}{*}{ Slope Face } & Direction $\left({ }^{\circ}\right)$ & N270 & N270 \\
\hline & Inclination $\left({ }^{\circ}\right)$ & 67 & 32 \\
\hline \multicolumn{2}{|c|}{ Height of Slope (m) } & 10 & 900 \\
\hline \multicolumn{2}{|c|}{ Cohesion $(C)\left(\right.$ ton $\left.\mathrm{m}^{-2}\right)$} & 11 & 11 \\
\hline \multicolumn{2}{|c|}{ Angle of friction $(\phi)\left(^{\circ}\right)$} & 20 & 20 \\
\hline \multicolumn{2}{|c|}{ Density of Rock $(\gamma)\left(\right.$ ton $\left.\mathrm{m}^{-3}\right)$} & 2.45 & 2.45 \\
\hline \multicolumn{2}{|c|}{ Unit weight of Water $\left(\gamma_{w}\right)\left(\right.$ ton $\left.\mathrm{m}^{-3}\right)$} & 1.0 & 1.0 \\
\hline \multicolumn{2}{|c|}{ Earthquake horizontal acceleration $(\alpha)$} & 0.08 & 0.08 \\
\hline \multicolumn{2}{|c|}{$\begin{array}{l}\text { Corresponding earthquake magnitude } \\
\text { (Richter Scale) }\end{array}$} & 7 & 7 \\
\hline \multicolumn{2}{|c|}{ Pore water pressure factor (no units) } & $\begin{array}{l}0 \text { (dry), } 0.5 \text { (moderately saturated), } \\
1.0 \text { (fully saturated) }\end{array}$ & $\begin{array}{l}0 \text { (dry), } 0.5 \text { (moderately saturated), } \\
1.0 \text { (fully saturated) }\end{array}$ \\
\hline
\end{tabular}

\section{SLOPE DESIGN AND REMEDIAL MEASURES}

The detailed stability analysis of the critical slope sections having possible planar mode of failure indicates that for the existing conditions (static dry) only 2 slope sections (SL2 and SL7) are stable (Fig. 11). The remaining 5 slope sections (SL1, SL3, SL4, SL5 and SL6) are unstable (Table 6). For the anticipated adverse condition (moderate saturation and dynamic), slope SL2 and slope SL7 are stable. However, the remaining slope sections (SL1, SL3, SL4, SL5 and SL6) would be unstable for anticipated adverse condition. Therefore, there is a need to provide remedial measures to the slope sections having a FoS less than 1.0 for the anticipated adverse conditions. Though, slope section SL2 and SL7 demonstrate a FoS of 1.45 and 1.13, respectively, for the existing slope geometry, these may become unstable for other geometric configurations if the slope geometry alters in future. Therefore, keeping all these considerations, an attempt has been made to workout a safe design for critical slope sections, including SL2 and SL7.

Remedial measures for slope sections having planar mode of failure

In the present study for the critical slope sections, a safe slope design has been worked out by adopting the technique proposed by Hoek and Bray, 1989. For each critical slope section the height is varied from a minimum $(5 \mathrm{~m})$ to a maximum $(50 \mathrm{~m})$ value for a given slope angle. Similarly, the slope angle for each slope has been varied from a minimum (greater than failure plane angle) to a maximum up to $85^{\circ}$. The factor of safety has been determined for the anticipated adverse conditions (dynamic moderately saturation). Thus, the calculated factor of safety for each combination of slope angle and slope height is plotted on a graph in which the slope angle is taken on the $\mathrm{X}$-axis and the height is taken on $\mathrm{Y}$ axis. Further, a contour representing a FoS of 1.2 was drawn over the graph to work out the safe slope angles (Fig. 12). For the road cut, a slope 
design of Fos equal to 1.2 is recommended (Hoek and Bray, 1989). Thus, the safe design cut slope angles for different heights, for all critical slopes having planar mode of failure, as determined by the above technique is presented in Table 9.

Table 9. Safe cut slope design angles for slope sections having potential planar mode of failure.

\begin{tabular}{lccccc}
\hline $\begin{array}{l}\text { Slope } \\
\text { Section }\end{array}$ & $\begin{array}{c}\text { Height* } \\
(\mathrm{m})\end{array}$ & $\begin{array}{c}\text { Slope } \\
\text { Angle }\left({ }^{\circ}\right)\end{array}$ & $\begin{array}{c}\text { Slope } \\
\text { Section }\end{array}$ & $\begin{array}{c}\text { Height* } \\
(\mathrm{m})\end{array}$ & $\begin{array}{c}\text { Slope } \\
\text { Angle }\left(^{\circ}\right)\end{array}$ \\
\hline \multirow{3}{*}{ SL1 } & $0-15$ & 54 & & $0-15$ & 83 \\
& $15-30$ & 47 & SL2 & $15-30$ & 75 \\
& $30-50$ & 44 & & $30-50$ & 71 \\
\multirow{2}{*}{ SL3 } & $0-10$ & 45 & & $0-15$ & 49 \\
& $10-20$ & 34 & SL4 & $15-30$ & 43 \\
& $20-30$ & 30 & & $30-50$ & 41 \\
\multirow{2}{*}{ SL5 } & $0-15$ & 54 & & $0-15$ & 69 \\
& $15-30$ & 47 & SL7 & $15-30$ & 63 \\
& $30-50$ & 44 & & $30-50$ & 61 \\
\hline
\end{tabular}

${ }^{*}$ Height is measured from top to bottom.

Slope Section SL6 cannot be stabilized by altering its geometry, as the factor of safety calculated for various combinations of slope angle and slope height is less than unity. Therefore, this slope section may be stabilized by providing rock bolts. An attempt has been made to quantify the reinforcement force and the number of rock bolts required to stabilize this slope section. For this purpose, the factor of safety is considered as 1.2 and the required reinforcement force has been calculated by using Equation (6). The reinforcement force has been calculated for anticipated adverse conditions. However, the other factors like weight, area, uplift water pressure and the water pressure in tension cracks have been calculated by using standard equations proposed by Sharma et al. (1995).

The reinforcement force for dynamic condition is determined by using Equation (6) proposed by Hoek and Bray (1989), where the FoS is taken to be equal to 1.2

$$
F=\frac{C A+\left[W\left(\cos \alpha_{p}-\alpha \sin \alpha_{p}\right)-U-V \sin \alpha_{p}+T \sin \beta\right] \tan \phi}{W\left(\sin \alpha_{p}+\alpha \cos \alpha_{p}\right)+V \cos \alpha_{p}-\mathrm{T} \cos \beta}
$$

The various symbols used in Equation (6) are already discussed earlier along with Equation (5). However, the additional symbols used in Equation (6) are; $\beta$, angle of the bolt installed from plane of sliding and $\mathrm{T}$, the bolt tension.

After calculating the amount of tension required, supporting the sliding rock mass for different installation angle for a design FoS, 1.2, for anticipated adverse conditions, the number and spacing between bolts is calculated for 11 ton bolt capacity. Table 10 shows the reinforcement force required to stabilize the slope section SL6.

Table 10 indicates that if a rock bolt is installed at an angle of $45^{\circ}$ the required reinforcement force will be minimum i.e., 38.74 tons. This is the total force required to stabilize the total slope face of length $12.54 \mathrm{~m}$. Therefore, if 11 Tons capacity rock bolts are used, total 4 rock bolts will be required at $3.5 \mathrm{~m}$ interval in one section. Further, these rock bolts may be provided laterally $3.5 \mathrm{~m}$ centre to centre as per the plan shown through Figure 13. These rock bolts may be cement grouted. For the present case the calculations were made for 11 tons rock bolt capacity however, the number of rock bolts can also be computed for other rock bolt capacities depending on the availability of the rock bolts. For this the total reinforcement force has to be divided by the available capacity of the rock bolt. This will provide the number of rock bolt required to stabilize the rock mass along SL6 slope section.

Table 10. Recommended bolt number and separation of bolts for SL6 slope section.

\begin{tabular}{lccc}
\hline $\begin{array}{l}\text { Rock bolt } \\
\text { Installation } \\
\begin{array}{c}\text { Angle } \\
\left.(\beta)()^{\circ}\right)\end{array}\end{array}$ & $\begin{array}{c}\text { Total } \\
\text { Reinforcement } \\
\text { Force (ton) }\end{array}$ & $\begin{array}{c}\text { No of Bolts of } \\
11\left(\text { tons } \mathrm{m}^{-2}\right)\end{array}$ & $\begin{array}{c}\text { Separation } \\
\text { of Bolts } \\
(\mathrm{m})\end{array}$ \\
\hline $45^{\circ}$ & 38.74 & 4 & 3.56 \\
$51^{\circ}$ & 41.27 & 4 & 3.34 \\
$57^{\circ}$ & 44.68 & 4 & 3.09 \\
$65^{\circ}$ & 51.19 & 5 & 2.70 \\
$73^{\circ}$ & 61.30 & 6 & 2.25 \\
$79^{\circ}$ & 73.08 & 7 & 1.89 \\
$83^{\circ}$ & 84.42 & 8 & 1.63 \\
$89^{\circ}$ & 111.32 & 10 & 1.24 \\
\hline \multicolumn{4}{c}{} \\
\hline
\end{tabular}



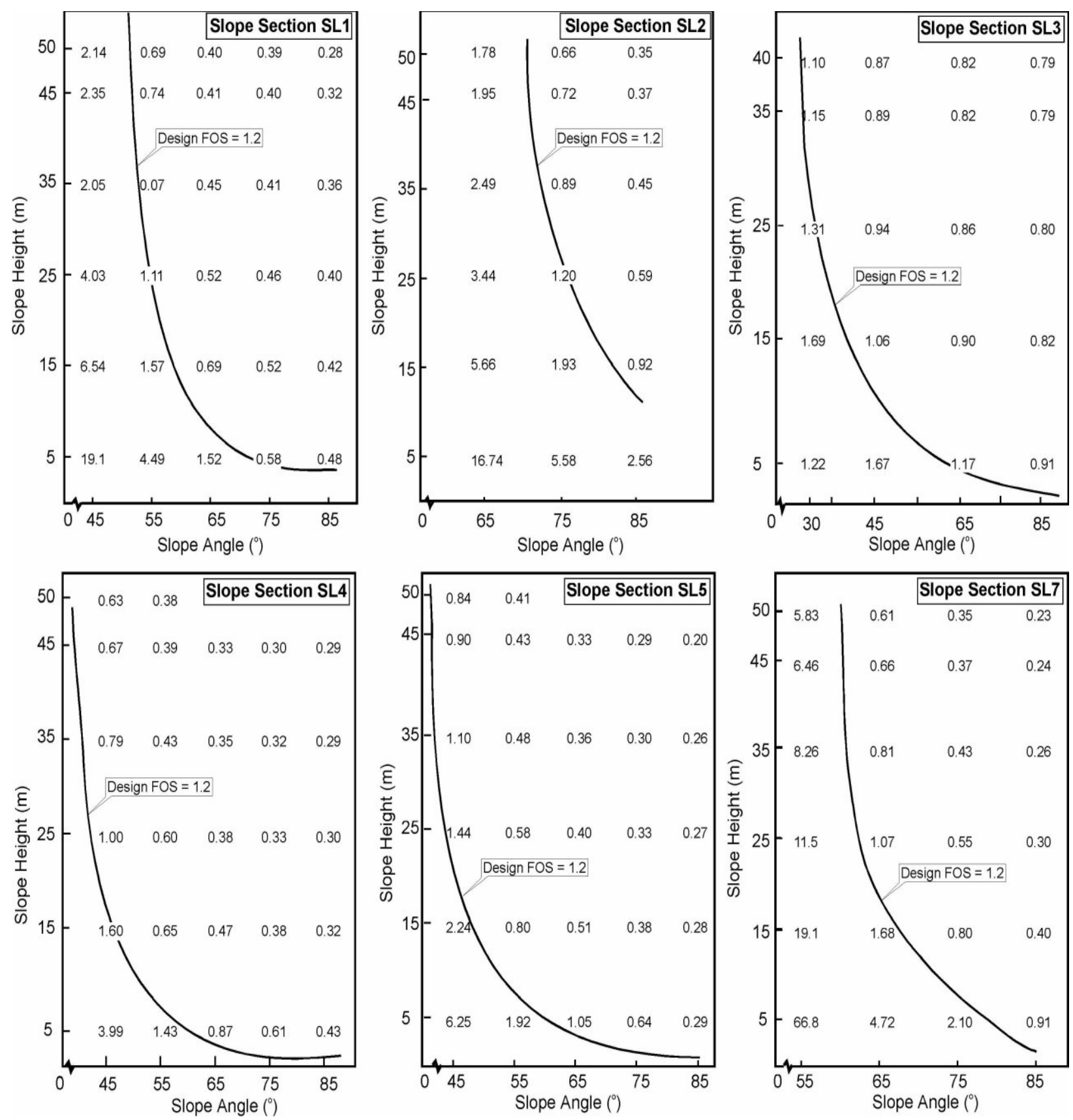

Fig. 12. Plot to determine safe slope design angles for slopes having planar mode of failure.

Remedial measures for slope section having wedge mode of failure

The stability condition of the road cut section having wedge mode of failure (SL8) will be stable for the existing conditions. However, the full slope section (SL8) demonstrates a FoS less than one, indicating slope instability for the existing condition. For the anticipated adverse conditions the road cut section (SL8) and the full slope section (SL8) may become unstable. Therefore, remedial measure has to be provided to this slope section. 


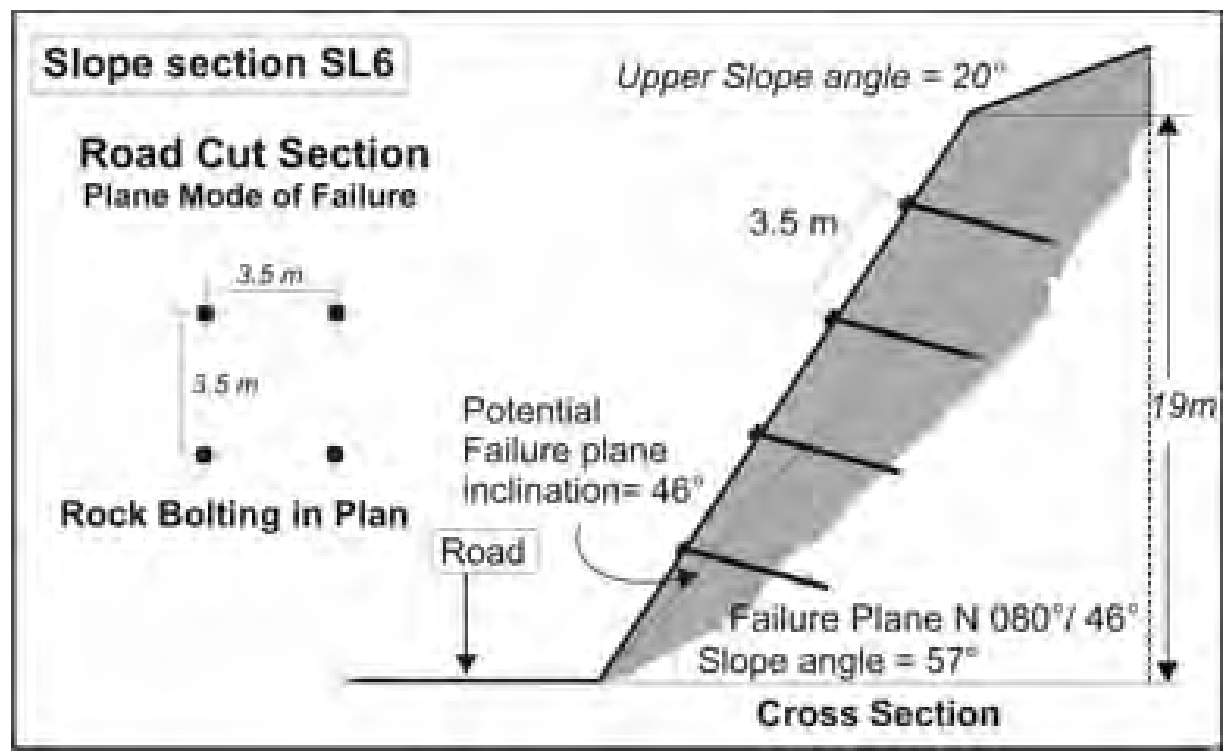

Fig. 13. Reinforcement plan for slope section SL6.

As indicated from the stability results, slope section SL8 in the road cut section is stable when there is no influence of water saturation i.e., when slope is dry. Even under dynamic condition when slope is dry, the Fos is as high as 20.9. However, when there is an influence of water saturation, the slope section becomes unstable for static and dynamic conditions. Therefore, if the drainage is controlled the slope section may demonstrate better stable conditions.

In order to improve the drainage conditions for SL8 slope section, horizontal collection drains in the crest region on the upper slope may be provided to collect the rain water and drain it away from the slope face. In addition, on the upper slope surface and on the slope face shotcreting with wire mesh and random rock bolts may also be provided. In addition to this, it is suggested to provide perforations in between the shotcreting surface, so that the water, if trapped in between the shot creating layer and the slope face, can be drained out.

\section{CONCLUSIONS}

During the present study an attempt has been made to identify the potentially unstable slopes. Based on field manifestations of instabilities, eight potentially unstable slopes were identified in the study area. Out of these, seven slope sections show potential for planar mode of failure whereas, one slope shows a potential for wedge mode of failure.

The plane failure analysis result indicates that for the existing conditions (static and dry) only slope sections SL2 and SL7 are stable whereas, the remaining slope sections are potentially unstable for existing and anticipated adverse conditions (Fos < 1.0). Therefore, there is a need to provide remedial measures to the slope sections, which have a FoS less than 1.0 for the anticipated adverse conditions. Accordingly, safe cut slope design and rock bolt anchors has been suggested for critical slope sections.

The result indicated that the road cut slope section (SL8) is stable for the existing condition (static dry) and will remain stable even for dynamic condition when it is dry. However, the full slope section (SL8) is not stable for existing and other anticipated conditions. For anticipated worst condition (dynamic moderately saturated), both road cut slope section (SL8) and the full slope section (SL8) will be unstable (FoS <1.0).

For critical slopes having possible planar mode of failure, an attempt was made to work out safe slope angles by adopting the technique proposed by Hoek and Bray (1989). Further, for slope section SL6 it has been found that slope could be stabilised by providing rock bolts of 11 tons capacity. The condition of slopes having wedge 
mode of failure (SL8) is more or less stable when the slope is dry. However, when there is an influence of water saturation, the slope section (SL8) becomes unstable for static and dynamic conditions. Therefore, in order to improve the drainage conditions on SL8 slope section, horizontal collection drains in the crest region on upper slope may be provided to collect rain water and drain it away from the slope face. Moreover, on the upper slope surface of SL8 slope section and on the slope face (SL8) shotcreting with wire mesh and random rock bolts can be provided. In addition to this, it is suggested to provide perforations in between the shotcreting surface, so that water trapped in between the shot creating layer and the slope face, can be drained out.

Thus, finally it is concluded that the slopes, in general, may not pose problems of instability to the road during the existing conditions (static dry). However, some slope sections may pose problems during the anticipated adverse conditions (moderately saturated with dynamic ground conditions). Therefore, remedial measures, suggested through this study may be adopted.

\section{ACKNOWLEDGEMENTS}

We are grateful to the Gilgel Gibe-II Hydroelectric project authorities for their kind cooperation. We are thankful to the head and staff of the Department of Earth sciences, Addis Ababa University for extending all kinds of support. We are also thankful to the three anonymous referees for giving very useful critical comments and suggestions based on which this paper has been improved.

\section{REFERENCES}

1. Anbalagan, R. (1992). Landslide hazard evaluation and zonation mapping in mountainous terrain. Eng. Geol. 32:269-277.

2. Barton, N. and Choubey, V. (1977). The shear strength of rock joints in theory and practice, Rock Mech. 10:1-54.

3. Barton, N. (1973). Review of a new shear strength criteria for rock joints. Eng. Geol. 7:287-330.

4. Bieniawiski, Z.T. (1989). Engineering Rock Mass Classifications. Wiley, New York, 251 pp.
5. Davidson, A. and Rex, D. (1983). Age of volcanism and rifting in south-western Ethiopia. Nature 283:657-658.

6. EEPCO (2004). Gilgel Gibe-II Hydro electric power project Geotechnical report for tunnel alignment. Unpublished technical report, Ethiopian Electric power corporation (EEPCO), Addis Ababa, Ethiopia, 150 pp.

7. Engdawork Mulatu, Raghuvanshi, T.K. and Bekele Abebe (2009). Landslide Hazard Zonation around Gilgel Gibe-II Hydroelectric Project, south-western Ethiopia. SINET: Ethiopian Journal of Science 32(1):9-20.

8. Engdawork Mulatu. (2005). Landslide hazard zonation mapping along right bank of Gibe river. Unpublished MSc Thesis, Addis Ababa University, Addis Ababa, Ethiopia, 100 pp.

9. Giday WoldeGabriel, Aronson, J.L. and Walter, R.C. (1990). Geology geochronology and rift basin development in the central sector of the Main Ethiopian Rift. Geol. Soc. Am. Bull. 102:439458.

10. Hoek, E. and Bray, J.W. (1989). Rock Slope Engineering, 3rd ed., Institute of Mining and Metallurgy, London, 358 pp.

11. International Society for Rock Mechanics (ISRM) (1981). Rock Characterization Testing and Monitoring (Brown, E.T, ed.) Pergamon Press Ltd, Great Britain, 211 pp.

12. Johnson, R.B. and Degraff, J.V. (1991). Principles of Engineering Geology, John Wiley and Sons, New York, 497 pp.

13. Kazmin, V. and SeifeMichael Berhe (1978). Geology and development of the Nazret area, Northern Ethiopian Rift sheet NC37-15, Memoir No. 3, 26 pp.

14. Laikemariam Asfaw (1986). Ethiopian earthquakes, earthquake parameters, strain release and seismic risk. In: Proc. of SARECESTC Conf. on Research Devl. and current research activities in Ethiopia, pp. 252-279.

15. Palmstrom, A. (1982). The volumetric joint count a useful and simple measure of the degree of jointing. In: Proceedings of the $4^{\text {th }}$ Int. Cong, pp. 221-228. IAEG, New Delhi, India.

16. Price, D.G. (2009). Engineering Geology Principles and Practice, Springer-Verlag, Berlin Heidelberg, 429 pp.

17. Sharma, S., Raghuvanshi, T.K. and Anbalagan, R. (1995). Plane failure analysis in rock slopes, Geot. and Geol. Eng. 13:105-113.

18. Sharma, S., Raghuvanshi, T.K. and Sahai, A. (1999). An engineering geological appraisal of the Lakhwar Dam, Garhwal Himalaya, India. Eng. Geol. 53:381-398. 
19. Singh, B. and Goel, R.K. (2002). Software for Engineering Control of Landslide and Tunnelling Hazard, 1st ed., A.A. Balkema Publishers, Netherlands. pp. 82-89.

20. Tierrcelin, J.J., Taieb, M. and Faure, H. (1980). Continental sedimentary basins and volcanotectonic evolution of the Afar Rift. Accad. Naz. Lincei 47:491-504.
21. Varnes, D.J. (1984). Landslide Hazard Zonation: A Review of Principles and Practice. UNESCO, Paris, 63 pp.

22. Yoon, W.S., Jeong, U.J. and Kim, J.H. (2002). Kinematic analysis for sliding failure of multifaced rock slopes. Eng. Geol. 67:51-61. 